Danyi, Gábor. "Csatári, Bence. 2017. Nekem írod a dalt. A könnyüzenei cenzúra a Kádár-rendszerben ['You Write This Song for Me: Pop Music and Censorship in the Kádár Era']. Budapest: Jaffa. 214 pp.” Hungarian Cultural Studies. e-Journal of the American Hungarian Educators Association, Volume 11 (2018) DOI: 10.5195/ahea.2018.333

\title{
Csatári, Bence. 2017. Nekem írod a dalt. A könnyüzenei cenzúra a Kádár-rendszerben ['You Write This Song for Me: Pop Music and Censorship in the Kádár Era']. Budapest: Jaffa. 214 pp.
}

\author{
Reviewed by Gábor Danyi , Eötvös Loránd University, Budapest
}

The main title of the book written by Bence Csatári, a journalist and historian of the pop music under communist times, paraphrases a popular song first performed by the rock band Locomotiv GT in 1975. The book's title itself thus highlights how censorship operated in post1956 Hungary. The song of Locomotiv GT directly addresses the listener, who is declared to be the only recipient of the song, Csak neked irom a dalt ['Only to you do I write this song']. In this context the title of Csatári's book, Nekem írod a dalt ['You Write This Song for Me'], suggests that a third party - let's call it a censor, representing the one-party state or reigning power-lies between the performer and its audience. While the presence of this third party vindicates the right of the addressee, it simultaneously diverts the song's original message, a shift that represents a significant reinterpretation of the effect that censorship and state attitudes had on the emergence of youth culture in Hungary.

How did censorship of popular music operate in the Kádár era? Which institutions were responsible for ideological control? Who were the actors involved in the production of pop music and how did they conceive of state censorship? These are the questions explored in Csatári's book, focusing on the period from the 1960s until the fall of the Iron Curtain in 1989. While the volume's subtitle, A könnyüzenei cenzúra a Kádár-rendszerben ['Pop Music and Censorship in the Kádár Era'], suggests a monographic work, Csatári apparently aimed at introducing the scene of popular music through the prism of a wide spectrum of different actors, as the book actually consists of seven interviews, with the first of them, with János Bródy, covering the first half of the volume, and then come six briefer interviews with a number of political figures and concert organizers of the time. Beyond the seven interviews the book also includes a short introduction, notes and index, and every interview is supported by a short bio of the given interviewee.

Bródy started his career in the mid-1960s as a songwriter of the first beat songs in Hungarian, first as a member of the beat band Illés and subsequently of Fonográf. He became one of the most emblematic figures of the pop-music world and creator of iconic song lyrics, well known also for those he wrote for the iconic rock singer Zsuzsa Koncz and for the rock opera István, a király ['Stephen, the King']. Csatári's interview with Bródy focuses primarily on

*mrgrabowsky@gmail.com

(cc) $\mathrm{Br}$

ULLS D-Serle
New articles in this journal are licensed under a Creative Commons Attribution 4.0 International License.

This journal is published by the University Library System of the University of Pittsburgh as part of its D-Scribe Digital Publishing Program and is cosponsored by the University of Pittsburgh Press 
Danyi, Gábor. "Csatári, Bence. 2017. Nekem írod a dalt. A könnyüzenei cenzúra a Kádár-rendszerben ['You Write This Song for Me: Pop Music and Censorship in the Kádár Era']. Budapest: Jaffa. 214 pp.” Hungarian Cultural Studies. e-Journal of the American Hungarian Educators Association, Volume 11 (2018) DOI: 10.5195/ahea.2018.333

possible interpretations of his lyrics while tracking shifts that indicated the limitations placed on the songwriter's artistic expression and the tone demanded for his songs, issues that depended on whatever form the actual Communist-Party line was taking at a given moment. Csatári clearly aims to have Bródy document all the semantic levels and subversive allusions contained in his songs. There is no doubt that Bródy was the master of doublespeak, managing to discuss political taboos via metaphors that were easily understood by a wide audience.

As happens also in other pieces written by Bródy, the rock opera István, a király, first performed in 1983 to great success, possessed multiple facets and called for many interpretations. Portraying the struggle for the Hungarian throne between Stephen I, a Christian, and his uncle, the pagan Koppány, the rock opera used a famous story in Hungarian history to explore the difference between a modern king and his uncle, who placed the maintaining of tradition over the future of the nation. On the one hand, the rock opera appeared to legitimize the Kádár system, in that a parallel could be drawn between Stephen I and Kádár, and between Koppány and Imre Nagy (who was executed by Kádár in 1958). On the other hand — as discussed later in the volume by another interviewee, Ernö Lakatos-by expressing national sentiments, the rock opera broke the taboo imposed on any public discourse regarding Hungarian minorities living in the neighboring countries.

In his interview Bródy discusses the obvious presence of censorship in the everyday life of songwriters, specifically due to the power of the Táncdal-és Sanzonbizottság ['Dance Music and Chanson Committee'], without whose permission no song could be published in Hungary, and the Magyar Hanglemezgyártó Vállalat ['Hungarian Record Company'], directed by Jenö Bors. While the latter was somewhat more liberal, both institutions intentionally maintained an atmosphere of uncertainty and obfuscation, so due to their absolute power and monopoly a songwriter wanting to have his or her work published was faced with no other alternative. As a result, musicians were forced to practice increased self-censorship, but as a counter-strategy they would also often submit an album containing a few harsher songs to the Committee in the expectation that those would be deleted while the others remained uncensored. In the case of Bródy, the larger public-broadcast station, the Hungarian Radio and Television, which followed a harsh line of censorship, did not broadcast most of the songs he wrote.

The Bródy interview provides a wealth of examples showing how censorship influenced cultural products on different levels, from a song's lyrics, to the cover of the record's album and the number of its copies and their distribution. To illustrate these constraints, Bródy discusses a number of songs that could not be performed in their original version. A characteristic example was the case of the song Elvonult a vihar ['The Storm is Gone'], which contained a line like De a zúgó vihar visszajöhet még' ['But the roaring storm may still come back'], which had to be rewritten since it was interpreted as potentially referring to the haunting memory of 1956. According to Bródy, sometimes the system's paranoia could lead to grotesque overinterpretation, as in the case of the song Barbara, which addressed the militancy of women but which the authorities interpreted as an allusion to Operation Barbarossa, the 1941 military attack issued by Nazi Germany against the Soviet Union in World War II.

The next four interviews, conducted with former representatives of various Party organs, bring the institutional structure controlling popular music into sharp focus. The first of these, conducted with Ildikó Lendvai, a former employee of the Cultural Department of the Central 
Danyi, Gábor. "Csatári, Bence. 2017. Nekem írod a dalt. A könnyüzenei cenzúra a Kádár-rendszerben ['You Write This Song for Me: Pop Music and Censorship in the Kádár Era']. Budapest: Jaffa. 214 pp.” Hungarian Cultural Studies. e-Journal of the American Hungarian Educators Association, Volume 11 (2018) DOI: 10.5195/ahea.2018.333

Committee of the Young Communist League and later of the Educational and Cultural Department of the Central Committee of the Party, well demonstrates the operation of the organizations belonging to the Young Communist League. Lendvai sees censorship as a complex system that categorizes cultural products as prohibited, tolerated or supported, and which includes different techniques, such as giving or withdrawing the right to perform, organizing or prohibiting trips abroad, influencing the number of the song's radio broadcasts, and more.

The third interviewee, Ernő Lakatos, who had joined the Party as early as 1948, had a career in a number of state publications and news agencies and reached the top of his career in the 1980s as the Head of the Party's Agitation and Propaganda Division. According to him, publications of the Young Communist League, such as Magyar Ifjúság ['Hungarian Youth'] and the more liberal Ifjúsági Magazin ['Youth Magazine'] on the one hand transmitted official ideology and on the other created space for popular topics that attracted the attention of young people. In spite of the fact that the fourth interviewee, Péter Nádori, spent forty-five years in the record industry, his interview refers only to the years 1972-1980, when as the head of the publishing department in Hungarian Record Company he was responsible for the graphic plans and textual content of album covers. According to Nádori, this institution was not (or not only) an ideological watchdog, but it also represented the interests of the professional music performers. He claims that in the history of this institution, only two incidents of classical censorship actually took place: the first concerned the cover of the album Utazás ['Journey'], which was censored because it was associated by the authorities with drugs and the hippie movement, while the second occurred because of the lyrics in the album Jelbeszéd ['Sign Language'] were judged to refer to the experiences of either 1956 or 1968 or both. Writer and poet Ferenc Baranyi, the subject of the fifth interview, worked for both youth magazines published by the Young Communist League: the Hungarian Youth and the more liberal Youth Magazine, while as a member of the Dance Music and Chanson Committee he was also responsible for controlling song lyrics. Baranyi was very self-protective in his interview, both admitting that ideological control was present and portraying himself as a poet responsible for the quality of lyrics rather than for their censorship.

The last two interviews in the volume were prepared with the program managers at institutions that regularly organized concerts, Katalin Nádor and Gábor Hajnal. These are the most refreshing interviews in the volume as they touch upon the so called "grey zone" where prohibited or hardly tolerated bands also could perform. Gábor Hajnal was the first and very well-known program manager of rock music in the Kádár era, and he occasionally also worked as disc-jockey. He introduced rock-and-roll bands to the audience of Egyetemi Szinpad [University Stage] as well as worked for the Ifjúsági Rendezö Iroda ['Youth Management Bureau'] controlled by the Young Communist League. From 1975 onward Katalin Nádor was the program manager of the Fövárosi Müvelödési Ház ['Municipal Culture House'], the Budai Ifjúsági Park ['Buda Youth Park'], and then the Petöfi Csarnok ['Petöfi Hall']. While reading Nádori's brief reminiscences one feels the irony apparent in her attitude toward socialist organs but also her enthusiasm and openness, which resulted in her providing many alternative music bands with the opportunity to perform, including Ági és a fiúk, Vágtázó Halottkémek, or the punk band, Aurora. 
Danyi, Gábor. "Csatári, Bence. 2017. Nekem írod a dalt. A könnyüzenei cenzúra a Kádár-rendszerben ['You Write This Song for Me: Pop Music and Censorship in the Kádár Era']. Budapest: Jaffa. 214 pp.” Hungarian Cultural Studies. e-Journal of the American Hungarian Educators Association, Volume 11 (2018) DOI: 10.5195/ahea.2018.333

Readers interested in the historical context of the collection should consult Csatári's previous book, Az ész a fontos, nem a haj ['Brain first, not hair'] (Budapest: Jaffa, 2015), which is a more systematic work based on archival materials and oral-history interviews. The collection under review here could be considered as a supplement to that earlier volume, as it does provide many examples and includes interesting details about institutional control over popular music, but it fails to present the phenomenon through a complex, systematic narration. Readers of the later volume are expected to be already familiar with the historical context, whereas supplementing the narration with other aspects is never even taken into consideration in it.

The broken and disemboweled cassette featured on the cover of Csatári's book obviously represents the censored texts and unpublished songs that were submitted to the official organs but never received "green light" for publication. However, this visual projection is also confusing as it does not take into account that behind the Iron Curtain during the Cold War cassettes were also the most important vehicle for unofficial music distribution. Recordings of alternative Hungarian music bands-including for example the A.E. Bizottság, Kontroll Csoport and Balaton - were being circulated on cassettes. Moreover, without cassettes on which young people recorded and then passed from hand to hand the songs broadcasted by Western radio stations, the Western influence (including beat, rock-and-roll, and the hippie movement) would also have had a much smaller significance, and socialist organs would not have been forced to counterbalance the blossoming youth movement to the extent that they did. (In the Soviet Union, unofficial recordings of radio broadcasts had their own name and were referred to as radizdat.) In reality, it was therefore the cassette that proved capable of defying censorship and creating a limited, unofficial public sphere for audio materials. In this sense the message of the book cover is very limiting and rather misleading.

Yet, on the whole, Csatári's book can be credited with the fact that it offers a far-from black-and-white picture of the popular music scene during the Kádár era. Thus the book's perspective is more complex than a simple confrontation between those who censor and those who are censored. Notwithstanding its balance, the book leaves the reader with a sense of loss regarding the spectrum of different actors, roles and strategies. While bands belonging to the tolerated cultural sphere are discussed in detail, there is much less about the prohibited sphere, namely alternative bands, subcultures of pop music and its cultic locales, even if the aforementioned proportions are in harmony regarding the extent of the tolerated and prohibited cultural spheres.

As mentioned in the book's foreword, another collection of interviews is expected to follow the present volume. Considering this undertaking a shift of scope could be very fruitful for the next work. The new collection could focus on the extent and ways in which the censorship of popular music during the Kádár regime differed from that in other socialist countries. This task could be achieved by the author's virtual crossing of borders and interviewing music editors of Western radios, too, as their broadcasts did penetrate the Iron Curtain, besides representatives of music bands from other socialist countries who toured in Hungary, or members of Hungarian minorities living in the neighboring countries, e.g. in Yugoslavia, where the record-publishing system was the most liberal in the bloc. Another possibility is that the new volume continue its focus on the relationship between the performer and the institutions controlling artistic production, this time including the voices of various 
Danyi, Gábor. "Csatári, Bence. 2017. Nekem írod a dalt. A könnyüzenei cenzúra a Kádár-rendszerben ['You Write This Song for Me: Pop Music and Censorship in the Kádár Era’]. Budapest: Jaffa. 214 pp.” Hungarian Cultural Studies. e-Journal of the American Hungarian Educators Association, Volume 11 (2018) DOI: 10.5195/ahea.2018.333

listeners or fans, the ones literally and practically addressed in the Locomotive GT's song cited before: Neked szól a gitár, Neked zörög a dob, Neked gyúlnak a fények, és csak Neked írom a dalt! ['For you the guitar plays, for you the drum rattles, for you the lights burn, only to you do I write this song']. 